\title{
The Agricultural Extension Agents Influence on the Uptake of Improved Sorghum Technologies in Embu County, Kenya
}

\author{
Evans L. Chimoita ${ }^{1, *}$, Cecillia M. Onyango ${ }^{2}$, John W. Kimenju ${ }^{2}$, Joseph P. Gweyi-Onyango ${ }^{3}$ \\ ${ }^{1}$ Department of Agricultural Economics, University of Nairobi, Kenya \\ ${ }^{2}$ Department of Crop Science and Protection, University of Nairobi, Kenya \\ ${ }^{3}$ Department of Agricultural Science and Technology, Kenyatta University, Kenya
}

Copyright $\mathrm{O} 2017$ by authors, all rights reserved. Authors agree that this article remains permanently open access under the terms of the Creative Commons Attribution License 4.0 International License

\begin{abstract}
The agricultural extension agents play important role in facilitating and guiding farmers towards implementing various agricultural value chain technologies. However, despite the availability of extension agents and improved agricultural technologies, there is minimal corresponding uptake and output on the farmers' farms. The current study therefore assessed the influence of extension agents on the uptake of improved sorghum technologies in Embu County, Kenya. The study sampled 51 government and private extension agents from four villages. Data was collected on the agent's socio-economic characteristics and extension, techniques. The study revealed that $65 \%$ of the respondents were male and had acquired education up to tertiary level. Further, the agents had acquired over twelve years work experience in disseminating various agricultural technologies. The study findings indicated that majority $73 \%$ of the agents disseminated technologies through farm visits, demonstrations, and agricultural shows visits and through radio technologies. There was an association $\left(x^{2}=96.7\right)$ between the extension agents and agents work experience with the work experience enhancing the uptake of improved sorghum technologies by farmers. Further, the work experience significantly $(\mathrm{p} \leq 0.00)$ influenced disseminating of the improved sorghum technologies among farmers. It was concluded that agents' gender, work experience, demonstrations techniques and farm visits, agricultural shows method complemented agents' work in disseminating the improved sorghum technologies among farmers.
\end{abstract}

Keywords Sorghum Improved Technologies, Socio-economic Factors, Institutional Factors

\section{Introduction}

Agricultural extension agents and progressive farmers play a complimentary role in influencing uptake and disseminating modern improved technologies between researchers, technical agents and other stakeholders Munyua and Stilwel [1]. In Kenya, the government extension services are provided by national and county government agencies and the Kenya Agricultural and Livestock Research Organisation (KALRO) Munyua and Stilwel [1]. According to Wanyama et al, [2] the private extension sector agents complement the government agencies. The private sector in Kenya include, Non-governmental organizations (NGOs), faith based organizations, progressive farmers, farm inputs and various cash crops agencies such as tea, coffee, sugar cane and wheat. However, Fisher and Vogel [3] asserted that majority of the extension agents both in private and government institutions in developing nations tend to restrict their contacts to the richer and large scale farmers willing to experiment with new technologies. Further, the study documented that large scale farmers use knowledge and skills acquired from extension agents to enhance their competence in production and accrue income from successful agricultural enterprises implementation Fisher and Vogel [3]. However, according to AGRA [4], agricultural extension service provision is crucial in disseminating information and technologies in the earnest to confronting food insecurity and poverty in Africa. Besides, the extension service provision acts as a pre-requisite for promoting technology uptake and its eventual use in increasing both livestock and crop productivity AGRA [4].

Related to this study, Kirimi et al., [5] documented that agricultural extension service provision serves as a means of delivering information to farmers, besides disseminating new technologies aimed at increasing production in both crop and livestock products. In addition to service provision, extension models such as participatory and integrated computer technologies (ICT) play important role in guiding and styling up the action of an extension system or an organization to achieve its goals and objectives towards 
effective adoption among the farming community Lavis et al., [6]. Further, extension model has been documented as a philosophy that informs, stimulates and guides agents on the system structure such as leadership, programmes, resource management and its linkages Okello, [7]. According to Aremu et al.,[8] extension agents convey or pass across new skills, technology, techniques or new methods of production in agriculture packaged in a model to ultimately improve the productivity and living standard of target farmer. Related to this study, Feder et al [9] asserted that, for successful modeled technology transfer, the extension agent must understand the farmers learning needs, challenges, priorities and opportunities as well as psychological process, semantic, physical and economic barriers to adoption of new technologies.

In addition to agents ability of agents to disseminate technologies across various value chains, Mukembo and Edwards, [10] asserted that extension models play complimentary roles in enhancing technology transfer. Moreover, Mukembo and Edwards, [10] documented that extension models include, educational institution based agricultural extension model, project based extension model, farming systems research extension model, the cost sharing extension model, information communication integrated and the participatory extension model. For instance in Kenya, the agricultural extension models guided by various techniques and avenues such as ASK shows in Kenya, farm demonstrations, government and private public field days, farmer to farmer chats, radio services, mobile phone technologies and computer based technologies enhance rapid adoption rates among farmers Mwadalu and Mwangi, [11].According to Doss, [12] the choice of extension model in Kenya by agents is dictated by factors such as availability of the of the farmer, availability of relevant institutional support and resources, suitability of methods or techniques, target and supportive, monitoring and evaluation of extension services. Besides, farmer's interest in various agricultural activities should be understood by extension agents' as guidance on the use and benefits of latest improved research technologies. In addition, Lavis et al., [6] documented that diffusion of knowledge and skills can achieve faster results outcome among farmers if research technologies are appropriately taken by agents during dissemination. Further, diffusion of research output can be also enhanced by qualified agents through simple documentary reviews, brochures and summaries of modern technologies to farmers.

Related to this study, Fisher [13] asserted that information transfer agents are important disseminators of relevant research, policy information and successful practices among farmers. Besides, agricultural extension agents translate research technologies into plain language that help farmers to acquire agricultural information and establishing a connection between research, producers and research users [Feder, et al., 9]. In addition, Neubert [14] asserted that participatory extension services involving multi-agencies enhance sustainable uptake of improved technologies. Jurgen, et al., [15] also asserted that the participatory research perspective is considered as the broader knowledge system in which farmers are embedded and evolved into the Agricultural Knowledge and Information System (AKIS) perspective. Jurgen, et al, [16] further documented multi-agencies and institutional support is very important in enhancing technology transfer through Agricultural Innovation Systems (AIS). According to Rivera and Sulaiman [17] information and technology transfer brokering by extension agents entails a broad range of tasks such as research, technologies and innovations development and goes beyond common knowledge a transfer. Related to this, Laurens et al., [18] also stated that extension agents and researchers play key roles in systems complementary facilitation and support service provision to farmers.

Contrary to foresaid theories and philosophy, small-scale farmers in arid areas still face problems such as receiving minimal extension services, limited access to latest agricultural information and lack of training and knowledge on improved technologies Nambiro, et al, [19] and CGIAR, [20].Further, transfer of appropriate research technologies to promote food security is a major priority for many developing nations including Kenya Nambiro, et al, [19].It is against this back drop the current study examines the greatest challenges facing the agricultural technology transfer, the availability of approaches and models to the end users and sustainability and the use of technology to meet the future challenges by farmers. The current study was therefore evaluatedinfluence of extension agents on the uptake of improved sorghum technologies in marginal areas of Embu county Kenya.

\section{Methodology}

The study was conducted in arid Mbeere north Sub-County, Embu County, Kenya. The region's topography slopes from North West to South East direction and located on the East of Mount Kenya between coordinates $0^{\circ} 41^{\prime} 18^{\prime} \mathrm{N}$ $37^{\circ} 55^{\prime} \mathrm{E}$, Gachimbi, [21]. The study employed a descriptive survey design suitable for describing information, data, events, perceptions and issues Mugenda and Mugenda, [22]. Further, the study purposively selected 51 out of 101 agents fromnational and county government ministry of agriculture, lead farmers, farmers groups and non governmental organizations data from Mbeere north, Embu county engaged in improved sorghum value chain MoA, [23]. Data on the extension agent's gender, work station, education level, experience, telephone technologies, demonstrations, ASK shows and radio techniques was collected from lead farmers, private and extension agents located in Njura, Kangai, Njarange and Kiambungu villages. Purposive sampling technique was used to select extension agents working within Mbeere north Sub-County, Embu county (Table 1). 
Table 1. Purposive sampling frame for extension agents

\begin{tabular}{cc}
\hline Institutions & Number of respondents \\
\hline MoA, government frontline extension agents & 19 \\
MoA Sub county government agents & 3 \\
Progressive lead farmers & 6 \\
Contact farmers & 21 \\
EUCORD, N.G.O agent & 1 \\
CLUSA, N.G.O agent & 1 \\
\hline Total & 51
\end{tabular}

Key. MoA- Ministry of Agriculture, EUCORD-European Union Cooperative for Rural Development, CLUSA-Cooperative League of United States of America

N.G.O-Non Governmental organization

\section{Data Sources, Collection Methods and Analysis}

Primary data was collected on agents' gender, education level and occupational experience, telephone technologies, demonstrations, ASK shows and radio technique. A pre-tested Likert scale questionnaire containing varied items was used to collect data from extension agents' perception on the use of participatory and integrated computer technologies (ICT) models and techniques in promoting the production and marketing of improved sorghum products. The extension staffs were asked to express their opinion on a scale of 1 to 5 , where 1 indicated a strong agreement with presented perception and $\mathbf{5}$ indicated strong disagreement with assertions on extension models and techniques enhancing production and marketing of sorghum value chain. Secondary data on the farmers' records, annual County agriculture reports, statistical abstracts, periodicals, journals, economic reviews and market reports were collected. The collected data was coded and analyzed using Statistical Package for Social Sciences (SPSS version 16). The descriptive study findings were presented through frequencies and percentages. Further Pearson's Chi-square test was further performed to determine the degree of association between variables.

\section{Results}

\subsection{Extension Agents Characteristics}

The study findings indicated that the majority $65 \%$ of extension agents' were male and 52\% had acquired education up to tertiary level while $24 \%$ of the agents up to secondary level (Table 2 ). In addition, $75 \%$ of the agents had an experience of over twelve years conducting extension work to farmers disseminating various technologies among farmers (Table 2).
Table 2. The extension agents' characteristics

\begin{tabular}{lcc}
\hline Agents characteristics & Number of agents & Percentage (\%) \\
\hline Male & 33 & 65 \\
Female & 18 & 35 \\
Educational levels & 4 & \\
Primary level & 12 & 08 \\
Secondary level & 27 & 24 \\
Tertiary level & 07 & 52 \\
Degree & 1 & 14 \\
Postgraduate & & 02 \\
Agents work experience & 07 & 14 \\
$\leq 8$ yrs & 05 & 10 \\
$\leq 10 y r s$ & 38 & 75 \\
$\leq 12$ yrs & 01 & 01 \\
$\leq 15 y r s$ & & \\
\hline
\end{tabular}

$\mathrm{N}=51$

\subsection{Technologies Disseminated by Extension Agents}

The study findings also revealed that $77 \%$ of the agents were exclusively engaged in disseminating sorghum production technologies on the farmers' farms while $18 \%$ disseminated marketing technologies and 5\% supported farmers in value chain technologies (Figure 1).

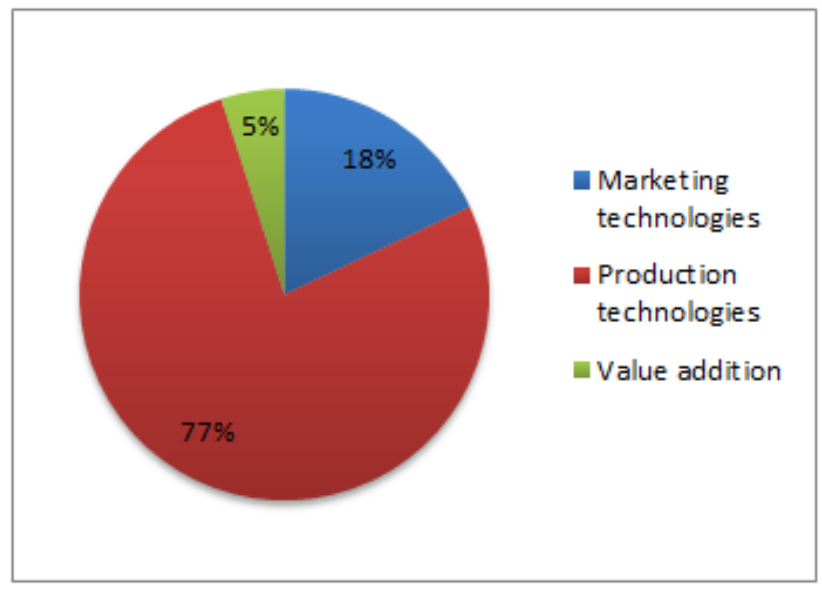

Figure 1. Disseminated technologies

\subsection{Association between Agents' Characteristics and Disseminated Technologies}

The results revealed an association between the agents' agents experience $\left(\chi^{2}=96.7\right)$ and agents disseminating production sorghum technologies which significantly $(\mathrm{p} \leq 0.00)$ contributed to dissemination of the improved sorghum technologies among farmers (Table 3). 
Table 3. Association between agents' characteristics and disseminated production technologies

\begin{tabular}{ccc}
\hline Agents characteristics & Chi-Square $\left(\chi^{2}\right)$ & $\mathrm{P} \leq$ Value \\
\hline Gender & 4.41 & 0.44 \\
Education level & 10.77 & 0.06 \\
Agent's experience & 96.74 & $0.00^{* *}$ \\
\hline
\end{tabular}

$\mathrm{N}=51$ Statistical significance levels $* * \mathrm{p} \leq 0.01,{ }^{*} \mathrm{p} \leq 0.05$

\subsection{Techniques Used by Agents in Promoting Improved Sorghum Technologies}

The study findings further showed that extension agents disseminated improved sorghum production technologies information through farm visits $(73 \%)$, agricultural shows visits $(80 \%)$, radio technologies $(57 \%)$, tours and excursions $(65 \%)$, farm group meetings $(59 \%)$ and through farm demonstrations (75\%) techniques (Table 4 ).

Table 4. Techniques used by agents in disseminating improved sorghum technologies

\begin{tabular}{ccc}
\hline Techniques & Number of agents & Percentage \% \\
Office visits & 24 & 47 \\
Telephone calls & 37 & 73 \\
Demonstrations & 38 & 75 \\
Farm meeting & 30 & 59 \\
Lead farmers & 19 & 37 \\
Tours and visits & 33 & 65 \\
Agricultural show visits & 41 & 80 \\
Radio programmes & 29 & 57 \\
\hline $\mathrm{N}=51$ & &
\end{tabular}

\subsection{The Association between Extension Techniques Used by Agents and Uptake of Improved Sorghum Technologies}

Table 5. The association between agents' extension techniques and production value chain

\begin{tabular}{ccc}
\hline Techniques & $\begin{array}{c}\text { Chi-Square }\left(\chi^{2}\right) \\
\text { Association }\end{array}$ & $\begin{array}{c}\mathrm{P} \leq \text { Value } \\
\text { Significance }\end{array}$ \\
\hline Farm visits & 42.8 & $0.00^{* *}$ \\
Telephone calls & 4.2 & 0.38 \\
Demonstrations & 30.4 & $0.00^{* *}$ \\
Farm meetings & 32.3 & $0.00^{* *}$ \\
Lead farmers & 17.2 & $0.00^{* *}$ \\
Tours and visits & 37.3 & $0.00^{* *}$ \\
Agricultural Shows & 6.8 & 0.28 \\
Radio programmes & 14.8 & $0.01^{* *}$ \\
\hline
\end{tabular}

Statistical significance levels ${ }^{* *} \mathrm{p} \leq 0.01,{ }^{*} \mathrm{p} \leq 0.05$

The techniques used by extension agents to disseminate production technologies were office visits, telephone calls, demonstrations, farm meetings, lead farmers, tours and visits, agricultural shows and radio programmes. The study revealed an association between farm visits $\left(\chi^{2}=42.8\right)$, demonstrations $\left(\chi^{2}=30.4\right)$ face to face chats $\left(\chi^{2}=32.3\right)$, radio programmes $\left(\chi^{2}=21.6\right)$, tours and visits $\left(\chi^{2}=37.6\right)$ and the agents engaged in disseminating improved sorghum technologies which significantly $(\mathrm{p}=0.00)$ contributed to the agents disseminating production technologies of improved sorghum technologies (Table 5).

Further, the techniques used by extension agents to disseminate marketing technologies were office visits, telephone calls, farm meetings, lead farmers, tours and visits, agricultural shows and radio programmes. There was also a strong association between face to face chats $\left(\chi^{2}=60.8\right)$ approach, farm meetings $\left(\chi^{2}=28.9\right)$ ASK visits $\left(\chi^{2}=41.8\right)$ radio programmes $\left(\chi^{2}=61.6\right)$ telephone calls $\left(\chi^{2}=21.2\right)$ and the agents engaged in disseminating improved sorghum marketing technologies which significantly $(p=0.00)$ contributed to the agents disseminating marketing technologies of improved sorghum products (Table 6).

Table 6. The association between extension techniques disseminated by agents and uptake of marketing technologies+

\begin{tabular}{ccc}
\hline Techniques & $\begin{array}{c}\text { Chi-Square }\left(\chi^{2}\right) \\
\text { Association }\end{array}$ & $\begin{array}{c}\mathrm{P} \leq \text { Value } \\
\text { Significance }\end{array}$ \\
\hline $\begin{array}{c}\text { Farm or home } \\
\text { Radio programmes } \\
\text { Mobile phone and } \\
\text { technologies } \\
\begin{array}{c}\text { Telephone } \\
\text { technologies }\end{array}\end{array}$ & 61.9 & 0.10 \\
Face to face chat & 8.3 & $0.00^{* *}$ \\
Farm meetings & 21.2 & 0.09 \\
Community Leaders & 60.8 & 0.04 \\
Agricultural show \\
visits
\end{tabular}

Statistically significance levels $* * \mathrm{p} \leq 0.01, * \mathrm{p} \leq 0.05$

\section{Discussion}

The current study findings indicated that extension agents were engaged in disseminating improved sorghum technologies whereby $65 \%$ were male agents while $52 \%$ agents had acquired education up to tertiary level (Table 2). Gender of the extension agent and educational levels are key determining factors in enabling transfer of technology uptake and decision making among farmers. The current study results could be attributed to the fact that both female and male extension agents disseminate information on new technologies depending on their areas of specialization. Related to this study, Chiligati [24] asserted that education levels and literacy levels form the prerequisite to agricultural technology adoption potential of among small scale farmers. Moreover, Asomoah, [25] asserted educational status and age are assumed to influence the farmers' adoption of many technologies as a result of the farmer decision making on the technical and economical of potentiality of adoption new technology. Further, Adetumbi, [26] documented that education level contributes to the competency of an agent 
in transforming information and knowledge into skills hence enhancing uptake of innovations in society to the farm. Besides, Piccoli et al., [27] established that the education level of an individual is a prerequisite to acquiring information and capacity to interpret and utilize the acquired information. In an argument that supports this view Adetumbi, [26] and Okello, [7] further argued that farmers who have spent less than ten years of schooling are less capable of acquiring and utilizing information sourced from the ICT/internet services among other modern technologies.

The current study findings revealed that $77 \%$ of the agents were exclusively involved in assisting farmers in disseminating improved sorghum technologies on farmers' farms (Fig 1). This could be attributed to the fact that majority of the agents were engaged directly with farmers as a result of funded promotion of gadam sorghum variety value chain in Mbeere. Related to these results, Andiema et $a l$, [28] and Evenson and Mwabu [29] asserted that work experience and establishment of extension agents forms a strong association and formal and informal linkages between farmers, researchers, innovators and eventual adoption of new technologies.

Moreover, the current study findings indicated that agents had worked in their stations for twenty years twelve years disseminating improved sorghum technologies. Further, the findings could be attributed to the fact that private and government agents' experience and financial support acted as motivating factors contributing to enhanced need of the agents to disseminate various information and innovations on various value chains including sorghum technologies. The current the study findings also in tandem with Mburu [30] and Gachimbi [21] study which documented that rapid and significant uptake of sorghum technologies was facilitated by experienced extension agents among Siaya west sorghum farmers. In addition, Czapiewshi et al., [31] documented that entrepreneurs are likely to embrace modern techniques in farming transactions when motivated and exposed to basic modern information and communication management by the experienced agents.

Further, there was a strong association between farm visits, office visits, demonstrations face to face chats, radio programmes, community leaders and agents were engaged in disseminating improved sorghum production technologies which significantly $(\mathrm{p}=0.00)$ contributed to disseminating of production technologies of improved sorghum varieties (Table 5). According to Okello [6], the effective uptake of information and technology requires harmonious synergy between agents and suitable extension model(s) for linking a farmer to relevant innovators, researchers, repository managers, agricultural extension policy formulators and extension agents. The association between mobile phone technologies, radio techniques and ICT extension model revealed significant relationships respectively contributing to dissemination and uptake of improved sorghum technologies. The results further showed extension agents rated television shows essential techniques in promoting production of sorghum products.

\section{Conclusions}

It was concluded that agents' work experience significantly contributed to the agents disseminating improved technologies among farmers. Further, demonstrations, farm visits, farm meetings, lead farmers, tour and visits and agricultural shows techniques complemented agents' disseminating the improved sorghum production technologies. Besides, radio programmes, face to face chats, farm meetings, community leaders and agricultural show visits complemented agents' disseminating the improved sorghum marketing technologies.

\section{Acknowledgements}

I appreciate the great financial support towards thesis writing from Association of African Universities, Ghana and the University of Nairobi, Kenya.

\section{REFERENCES}

[1] Munyua, H. and Stilwell, C.(2010). A mixed qualitative and quantitative participatory methodology. A study of the agricultural knowledge and information system (AKIS) of small-scale farmers in Kirinyaga district, Kenya

[2] Wanyama, J.M., Njue, E.K. and Kidula, N.L.(1996). Evaluation of sorghum technology adoption levels in Homa Bay district. In: Fungoh, P.O and Mbadi, G.C.O., Focus on Agricultural Research for sustainable development in a changing Economic ent. Proceedings of the 5th KARI Scientific Conference, 14th -16th October 1996. KARI, p. 360-369.

[3] Fisher, C. and Vogel, E. (2008): Locating the Power of In-between: How Research Brokers and Intermediaries Support Evidence-based Pro-poor Policy and Practice, Brighton: IDS.

[4] Alliance for a Green Revolution in Africa AGRA (2013). Africa Agriculture Status Report: Focus on Staple Crops. Nairobi, Kenya, AGRA.

[5] Kirimi, J. N., Mwangi, J. G. and Nkurumwa, A. O. (2013).Climate Change Challenges and Adaptation Strategies among the Pastoralists of Laikipia County, Kenya. International Journal of Agricultural Extension, 01 (01), 20-30. Retrieved from http://escijournals.net/IJER. May 2015

[6] Lavis, J.N., Lomas, J., Hamid M. and Sensankaybo, N.K. (2006): Assessing Country-level Efforts to Link Research to Action; Bulleting of the World Health Organisation 84: (8): 620-628

[7] Okello J., Ofwona-Adera, E., Mbatia, O.L.E and Okello R.M (2010): Using ICT to integrate small holders farmers into agricultural value chain; the case of DvuMNef project in Kenya: International Journal of ICT Research development in Africa, 


\section{Vol, 1:23-37}

[8] Aremu P.A., Kolo I. N., Gana A.K., Adelere F. A. (2015). The crucial role of extension workers in agricultural Technologies transfer and adoption, Global Advanced Research Journal of Food Science and Technology (Vol. 4(2) pp. 014-018, Available online http://garj.org/garjfst/index.htm Accessed on 11.05 .2016

[9] Feder, G., Willett, A., \& Zijp, W. (2001). "Agricultural Extension: Generic Challenges and the Ingredients for Solutions," In S. Wolf and D. Zilberman (eds.), Knowledge Generation and Technical Change: Institutional Innovation in Agriculture. Boston, Mass: Kluwer.

[10] Mukembo, C., \& Edwards, M. (2015). Agricultural extension in Sub-Saharan Africa During and After its Colonial Era: The case of Zimabwe, Uganda and Kenya; Journal of International Agricultural and Extension Education, volume 22:Issue 3

[11] Mwadalu, R., and Mwangi., M.(2013). The potential role of sorghum in enhancing food security in semi-arid eastern Kenya: A review, Journal of Applied Biosciences (71) :57865799

[12] Doss, C.R. (2003).Understanding Farm Level Technology Adoption: Lessons Learned from CIMMYT's micro surveys in Eastern Africa. CIMMYT Economics Working Paper 03-07. Mexico, D.F.: CIMMYT

[13] Fisher, C.(2011): Knowledge Brokering and Intermediary Concepts. Analysis of an e-discussion on the Knowledge Brokers' Forum, Brighton: Impact and learning Teams, IDS.

[14] Neubert, D. and Neef A. (2011): Stakeholder Participation In Agricultural Research projects: A Conception Framework for Reflection and Decision-making, Agriculture and Human Values. 28 p. 179-194.

[15] Jurgen, H., Murwira, K., and Connolly, M., (2000): Learning Together Through participatory Lessons from Asia, Africa and Latin America. Network Paper 21. Overseas Development Institute, London, UK; 58 pp. 7341

[16] Jurgen, H., Murwira, K., and Connolly, M., (2000): Learning Together Through participatory Lessons from Asia, Africa and Latin America. Network Paper 21. Overseas Development Institute, London, UK; 58 pp. 7341

[17] Rivera, W. and Sulaiman, R.V, (2009): Extension Object of Reform, Engine for Innovation" Outlook on Agriculture $38: 3: 267-573$

[18] Laurens K., Marc S., Cees, L., Kilelu, C.(2012): Advances in Knowledge Brokering in the Agricultural Sector: Towards Innovation System Facilitation. Knowledge Management for Development Journal, 43 (5).

[19] Nambiro, E., Omiti, J., \&Mugunieri, L. (2006, August).Decentralization and access to agricultural extension services in Kenya. Contributed poster presented at the International Association of Agricultural Economists Conference, August 12- 18. Gold Coast, Australia.

[20] CGIAR. (2013). "Research on Agricultural Extension Systems: What Have We Learnt and Where Do We Go From Here?" Workshop Organized by the CGIAR Research Program on Policies, Institutions and Markets. October 15-16, Washington DC, USA. CGIAR.

[21] Gachimbi, L.,Kamoni, P., Wanjogu, S.N, Macharia P.N, and
Gicheru, P.(2007): Land Use Practices In Mbeere District: Biophysical And Socio Economic Challenges, Copping Strategies And Opportunities: A Baseline Survey Report

[22] Mugenda, O.M, and Mugenda, A., G. (1999): Research methods - Quantitative and quantitative approaches. Nairobi: Acts Press

[23] Ministry of Agriculture (2010): The Annual Report, Crop Development Division, Mbeere Sub-county, Embu County, Kenya.

[24] Chiligati, J., E.(2010). Factors influencing research -Extension - Farmer linkages in Tanzania: A case of the western agricultural research zone. A dissertation submitted in partial fulfilment of the requirements for the degree of Master of Science in agricultural education and extension of Sokoine University of agriculture, Morogoro, Tanzania.

[25] Asamoah, C. andSoniia, D. (2012): Video as a tool for agricultural extension in Africa : A case study from Ghana Sustainable Tree Crops Program, International Institute of Tropical Agriculture , Ghana, Retrieved from http://www.treecrops.org/links/training May, 2015

[26] Adetumbi, (2013): Assessment of Educational levels and use of selected information communication technologies for extension service delivery: Implication for Agricultural Development in Nigeria. International Journal of Agricultural Management and Development, 3(2)

[27] Piccoli, G., Ahmed, R.., Lives, B., (2001): Web based virtual learning environments; A Assessment of framework in Basic IT skills Training, MLS Quarterly, Vol, 25:40-426

[28] Andiema, C. E, Nkurumwa, O.A, Amudavi, M, D. (2014). Socio-Economic Factors Influencing Adoption of EnergySaving Technologies among Smallholder Farmers: The Case of West Pokot County, Kenya, International Journal of Agricultural Management and Development (IJAMAD) Retrieved on 23.09.2016

https://www.researchgate.net/publication/299471038

[29] Evenson, R. and G. Mwabu (1998): The effects of Agricultural Extension on Farm yields in Kenya. Economic Growth Center Discussion Paper No. 798. Yale University, New Haven.

[30] Mburu, C. (1996): Research and Production constraints of sorghum in Kenya. A Paper Presented at a Workshop on Breeding for Disease Resistance with Emphasis on durability, for Eastern, Central and Southern Africa. Njoro, Kenya. 3rd $7^{\text {th }}$ October, 1994.

[31] Czapiewshi, R, Banski J., Bednarek S., Konopski M., (2013). The use of ICT in Mazovian Agriculture: In; P. Chmielinski, A. Baer. Nawrocka (Eds), Knowledge as a factor of rural development, Rural areas and Development 10: 45-57

[32] Cheplogoi, S. K., and Udoto, M. (2013): Contribution of Agriculture Related Activities of Women Groups to Household Income Levels and Food Security in Barwessa Division, Baringo County, Kenya, International Journal of Advanced Research , 1 (8), 85-92

[33] Kamau, F. (2006): Challenges in Provision of Agricultural Extension Services in Kenya: An Evolution From Public to Public- Private Partnership, Paper presented during $10^{\text {th }}$ Africa Forum, Windhoek, Namibia, $30^{\text {th }}$ Oct $-3^{\text {rd }}$ Nov. 2006

[34] Kwapong. O.A (2008). Policy implication for using ICT for empowering rural women in Ghana. The Turkish online 
Journal of education Technology. Vol, 3:35-45

[35] MuuiC. W, Muasya R. M, Kirubi D. T. (2013): Baseline Survey on Factors Affecting Sorghum Production and Use in Eastern Kenya; African Scholarly Science Communication Trust, Nairobi Kenya

[36] Robinson, E. J., and Maganga F. (2009): The Implications of Improved Communication for Participatory Forest
Management in Tanzania, African Journal of Ecology, 47: $171-178$

[37] Soniia, D. and Asamoah, C. (2011): Video as a tool for agricultural extension in Africa : A case study from Ghana Sustainable Tree Crops Program, International Institute of Tropical Agriculture , Ghana, Retrieved from http://www.treecrops.org/links/training May, 2015 